\title{
Beata Popczyk-Szczęsna \\ Dramaturgia współtworzenia znaczeń wypowiedzi scenicznej. \\ Na marginesie lektury \\ Tekstów dla (Starego) Teatru Pawła Demirskiego
}

\begin{abstract}
Beata Popczyk-Szczęsna, Dramaturgia wspóttworzenia znaczeń wypowiedzi scenicznej. Na marginesie lektury Tekstów dla (Starego) Teatru Pawła Demirskiego [Dramaturgy of co-creating meanings of the stage statement. Aside reading Paweł Demirski's Texts for the (Stary) Theatre]. „Przestrzenie Teorii” 36. Poznań 2021, Adam Mickiewicz University Press, pp. 163-175. ISSN 1644-6763. DOI 10.14746/pt.2021.36.10.

The article deals with dramaturgy in the broad sense of the term - as a written creative work and the characteristic feature of human activities: artistic and social. The starting point for these discussions is the publication of an anthology of Paweł Demirski's theatrical texts commissioned by the National Stary Theatre in Krakow. The book is an excellent testimony to stage creativity because it contains conversations with the author and actors about the stages of work in the performance. The article presents reflections on the dramaturgy of the process of creating a text and a theatrical performance, the characteristics of Paweł Demirski's writing and the content arrangement in the anthology. Reading this book is a peculiar aesthetic experience and a challenge for the reader. The dramaturgy of the message leads to the dramaturgy of its reception: the reader updates and co-creates meanings of theatrical texts, according to individual knowledge and sensitivity. Aesthetic experience is shaped by combining different mental spaces: it is reading a text / seeing a performance.
\end{abstract}

KEYWORDS: dramaturgy, texts for the theatre, stage statement, aesthetic experience

Teoria i praktyka pisania dla sceny nabrały dziś niezwykle dramaturgicznego wymiaru. Używając tych określeń, nawiązuję do różnych konotacji pojęć „dramaturgia” i „dramaturgiczny”, dziś często nie tylko używanych w odniesieniu do twórczości teatralnej - na oznaczenie zbioru dzieł dramatycznych czy też scenicznych praktyk przygotowywania scenariusza przedstawienia - lecz także przywoływanych w refleksji naukowej na temat wielu zjawisk pozaartystycznych, do opisu specyfiki świata ludzkich doświadczeń. Słowo „dramaturgia” jest przecież z powodzeniem wykorzystywane przez badaczy performansów życia społecznego do analizy różnych aktywności jednostki bądź grupy ludzi jako pojęcie 
określające tę część złożonego i nieprzerwanego procesu ustanawiania rzeczywistości pozateatralnej, która dotyczy kompozycji działań i wypadków, układu i przebiegu tego, co się dzieje i jak jest postrzegane, doświadczane"1.

Zainteresowanie przygotowaniem, treningiem, przebiegiem czynności, czyli „dzianiem się” tego, co przez ludzi czynione, stanowiące konsekwencję zwrotu performatywnego w kulturze, łączy artystów i badaczy z różnych dyscyplin nauk humanistycznych, którym pozostaje bliska idea work in progress. Ujęcie procesualne, zdarzeniowe - tak zjawisk społecznych, jak i twórczości artystycznej, w ramach której istotniejszy niż gotowy „wytwór estetyczny” jest sam proces jego powstawania - pozwala mówić (za performatykiem Dariuszem Kosińskim) o dramaturgii różnych działań twórczych, jednostkowych i zbiorowych, o dramaturgii przedstawień społecznych i par excellence - o „dramaturgii życia”:

Dramaturgia teatralna może być uznawana za szczególny przypadek dramaturgii istniejącej we wszystkich sferach życia. [...] Tak rozumiana dramaturgia określa i opisuje te warstwy przedstawień wszelkiego rodzaju, które nie mieszczą się lub mieszczą z trudem w pojęciu widowiska jako - dosłownie - tego, co widać. Opisuje natomiast, czy też próbuje opisać, pracę wzoru: proces jego wykorzystywania, przekształcania i ustanawiania ${ }^{2}$.

Zestawiając stwierdzenia krakowskiego badacza z ustaleniami naukowców z poznańskiej szkoły dramatologicznej, a zwłaszcza z koncepcją doświadczenia dramatycznego autorstwa Anny Krajewskiej², nietrudno wnioskować, że tradycyjna nomenklatura związana z teatrem, a szczególnie takie pojęcia jak dramat, dramaturgia, dramatyczność, powracają w najnowszym dyskursie teoriopoznawczym w nowej odsłonie - jako matryca pojęciowa, regulująca obserwację współczesnych zjawisk i procesów kulturowych okiem przyzwyczajonym do wielu medialnych zapośredniczeń i spojrzeniem sterowanym performatyczną wrażliwością. Postrzeganie rzeczywistości jako obszaru dynamicznych, nieprzewidywalnych zdarzeń, zderzeń, przemieszczeń niesie ze sobą zarówno sporo zagrożeń, jak i potencjał twórczy, jeśli oczywiście przyjmiemy za dobrą monetę to, że doświadczanie świata i różne formy „świadczenia o tym, czego się doświadczyło", to działania pełne sprzeczności, napięć i zwrotów. Przekonanie o „złożonej, palimpsestowej” strukturze doświadczenia

\footnotetext{
${ }^{1}$ D. Kosiński, Performatyka. W(y)prowadzenia, Kraków 2016, s. 47.

${ }^{2}$ Ibidem, s. 48.

${ }^{3}$ A. Krajewska, Dramatyczna teoria literatury. Zarys problematyki, Poznań 2009, s. $26-45$.

${ }^{4}$ R. Nycz, Poetyka doświadczenia, Warszawa 2012, s. 149.
} 
skłania więc ostatecznie do ujęcia procesu poznania nie tyle jako reprezentacji uprzednio danego i niezależnie istniejącego świata, lecz raczej jako interaktywnego procesu wzajemnego formowania (współkonstruowania) tego, co wewnętrzne, i tego, co zewnętrzne, podmiotu i przedmiotu, umysłu i świata ${ }^{5}$.

\section{II}

Inspiracją do niniejszych rozważań jest przypadek szczególny, czyli publikacja antologii tekstów dla teatru Pawła Demirskiego ${ }^{6}$. W moim przekonaniu jest to dobry powód do refleksji na temat dramaturgii w szerokim artystycznym i pozaartystycznym - znaczeniu tego pojęcia. Publikacja, będąca zbiorem utworów scenicznych autora, stanowi znakomite świadectwo współpracy dramaturga z aktorami (dramaturga będącego swego rodzaju „łącznikiem między zespołem a różnorodnymi grupami widzów”, jak pisze Wojciech Baluch ${ }^{7}$ ), a w jeszcze szerszym ujęciu - antologia wydana przez Narodowy Stary Teatr jest w swym założeniu edytorskim materialnym ekwiwalentem procesu pracy nad spektaklem jako formą współczesnej praktyki artystycznej i zarazem społecznej. Na przykładzie tej publikacji można śmiało podjąć rozważania o dramaturgii rozumianej jako „układ, kompozycja tego, co czynione"

Kompozycja ta ma przy tym - co koniecznie trzeba podkreślić - charakter dynamiczny, częściowo wynikający z zakładanego przebiegu, częściowo z wyłaniającego się i/ lub modyfikowanego w trakcie działań modelu wzorca kulturowego. Dramaturgia nie dotyczy więc tylko tego, co istnieje jako scenariusz wyjściowy, ale także tego, co pojawia się w procesie kreacji i recepcji ${ }^{9}$.

Z jednej strony zatem Teksty dla (Starego) Teatru Pawła Demirskiego stanowią ciekawe przedsięwzięcie wydawnicze, potwierdzające zmiany i przemieszczenia w obszarze najnowszej twórczości dla teatru - jako praktyki łączącej w sobie różne formy współpracy artystycznej i niedającej się tak łatwo podporządkować modelowym ujęciom. Z drugiej strony antologia jest ważnym dokumentem konkretnej pracy teatralnej, to znaczy rejestruje i reprezentuje momenty dynamicznej, pełnej dramaturgii relacji

${ }^{5}$ Ibidem, s. 151.

${ }^{6}$ P. Demirski, Teksty dla (Starego) Teatru, red. A. Dąbek, Kraków 2020.

${ }^{7}$ W. Baluch, Dramaturgia, [w:] Performatyka. Terytoria, red. E. Bal, D. Kosiński, Kraków 2016, s. 59.

${ }^{8}$ D. Kosiński, op. cit., s. 47-48.

${ }^{9}$ Ibidem. Zob. także: D. Kosiński, Dramaturg jako medium, [w:] Dramaturg $w$ teatrze, literaturze, sztuce, red. W. Baluch, A. Krajewska, Poznań 2019. 
osobowej powstałej w związku z projektami scenicznymi, rozwijającej się w toku prób i podczas konfrontacji z widownia, a także obliczonej na reakcję przyszłych czytelników książki, którzy moga, ale nie musza przecież być widzami teatru Moniki Strzępki i Pawła Demirskiego. Potencjał dramatyczny (nomen omen) publikacji tkwi w zamyśle połączenia w obrębie tomu kilku tekstów napisanych na zamówienie Starego Teatru, rozmów z dramaturgiem, aktorami i inspicjentką oraz kilku scen dodatkowych, strzępków pracy dramatopisarskiej autora, odrzuconych bądź niewykorzystanych w przedstawieniach. Antologia tekstów Pawła Demirskiego (a ściślej rzecz ujmując, fragment $\mathrm{z}$ dużego dorobku pisarskiego autora powstały w efekcie zatrudnienia w Starym Teatrze) jest jednocześnie śladem dramaturgii pracy nad spektaklem, dramaturgii „rzeczy czynionych” w konkretnym układzie personalnym: artystycznym i międzyludzkim. Jest również zaproszeniem dla czytelnika do uważnego odbioru, do uaktywnienia „litery” tekstów, zredagowanych (co istotne!) po przedstawieniach. Tak właśnie deklaruje intencję całego projektu autorka wstępu i zarazem redaktorka książki Agata Dąbek:

\begin{abstract}
Ktoś mógłby teraz powiedzieć: zaraz, ale o czym my tutaj cały czas rozmawiamy: o tekście czy o przedstawieniu? O czytaniu czy o próbach, o graniu, reżyserowaniu etc.? Odpowiedź brzmi: o tym i o tym. Bo lektura tekstów Demirskiego, chyba jak żadna inna, przynajmniej w moim mniemaniu, uzmysławia, że czytanie sztuki jest przedstawieniem. Zawsze czyta się ja „teatralnie”. I w tym wypadku zwraca się na to uwage niejako automatycznie, bo ze względu na liczne „luki” niemal cały „świat” trzeba samemu „postawić na scenie”. W jaki sposób? O tym decyduje już każdy czytelnik indywidualnie, uruchamiając swoje zasoby wiedzy (również na temat stylów i konwencji teatralnych), pomysłowość, a także uwzględniając własne upodobania estetyczne, poglądy i potrzeby posiadane w danym momencie ${ }^{10}$.
\end{abstract}

\title{
III
}

Twórczość dramaturgiczna Pawła Demirskiego jest układaniem tekstów do/w czasie prób przedstawienia. Ten styl pracy wyróżnia artystę spośród zarówno autorów piszących „gotowe” teksty dramatyczne, jak i dramaturgów, którzy przygotowują scenariusze teatralne na podstawie wielu źródeł, kompilując materiał tekstowy o różnorodnym, niekoniecznie artystycznym charakterze. Zresztą w tym miejscu nie chodzi mi o podziały i przeciwstawienia, uruchamiające dyskusje czy nawet gorące spory wśród teoretyków i praktyków teatru. Zależy mi bardziej na podkreśleniu specyfiki

${ }^{10}$ A. Dąbek, Od przedstawienia do tekstu - iz powrotem, [w:] P. Demirski, op. cit., s. 14. 
twórczości dla sceny „człowieka pióra”, bo takim jest niewątpliwie Paweł Demirski - twórczości dramatopisarskiej w jej dramaturgicznym wymiarze, to znaczy przebiegającej w trybie konfrontacji autora z aktorami. Demirski, jak powszechnie wiadomo, nie przynosi na próby gotowego tekstu scenicznego; przedstawia zespołowi zaledwie jakieś poszczególne fragmenty, sceny, które następnie w czasie pierwszych prób sytuacyjnych stają się materiałem czytanym przez aktorów, przedmiotem aktorskich improwizacji, intuicyjnych rozpoznań „świata przedstawionego”. Ten świat, wymyślony przez autora w jakimś ogólnym zarysie, powstaje in statu nascendi, rodzi się z fragmentarycznego zapisu słownego i dyskusji z wykonawcami - ale nie do końca. Autor powraca bowiem do pisania poza sceną i na podstawie spotkań z aktorami, podczas których doszło do wypróbowania i uzupełniania tekstu, dopisuje resztę, układa kolejne sceny, projektuje „całość” scenariusza, i tak podlegającą późniejszym przekształceniom w toku prac reżysersko-aktorskich. Co jednak ciekawe, zmiany wprowadzane w celu uzyskania spójności przekazu dotyczą zazwyczaj większych partii tekstu, a nie poszczególnych replik czy epizodów. Interesujące w tym względzie pozostaje świadectwo inspicjentki Hanny Nowak, współpracującej z Moniką Strzępką przy wielu spektaklach (nota bene oddanie głosu aktorom i inspicjentce to ważny gest, wzmacniający u czytelnika książki przekonanie o znaczeniu „rzeczy czynionych” przez grupę zaangażowaną do pracy nad spektaklem i o dramaturgii tego całego procesu działań artystyczno-organizacyjnych). W wywiadzie z Hanną Nowak we fragmencie nawiązującym do przygotowań Bitwy warszawskiej 1920 czytamy, że Paweł Demirski i Monika Strzępka

nie robią skrótów wewnątrz scen, tylko ścinają całe sceny. Taką mają metodę. Wtedy trochę tych scen wypadło, ale spektakl stał się bardziej zwarty. Długo je trzymałam w swoim egzemplarzu, nie wyrzucałam ich, bo mi było żal. Pozostał dokument-można poczytać ${ }^{11}$.

Praktykę pisarską Pawła Demirskiego, realizująca się w ramach długiego, nierzadko mozolnego procesu powstawania tekstu, można określić mianem dramaturgii (współ)tworzenia wypowiedzi scenicznej - z cała dynamiką i nieprzewidywalnością przebiegu zdarzeń w pracy twórczej całego zespołu teatralnego, na którą składają się: układanie scenariusza w etapach, rozwijanie go dzięki informacji zwrotnej od aktorów i kształtowanie replik z myślą o wykonaniu partytury słownej z uwzględnieniem jej „sprawczości” i w zgodzie z „technologią przedstawienia” (tych pojęć używam za Williamem

${ }^{11}$ Aktualnie i ponadczasowo. Rozmowa $z$ inspicjentka Hanna Nowak, [w:] P. Demirski, op. cit., s. 36 . 
B. Worthenem ${ }^{12}$ ). Jest to zatem nie tylko przykład pracy teatralnej tandemu reżyserka-dramaturg, lecz także wariant teatru aktorskiego z mocną pozycją autora jako twórcy tekstu, nadrzędnego dysponenta reguł utworu scenicznego. Paweł Demirski z właściwym sobie dystansem wobec dwupodziału władzy nad tekstem (model autorski kontra model reżyserski) stwierdza dobitnie:

Moim zdaniem to w ogóle fałszywy podział. Bo teatr jest przede wszystkim aktorski, czyli że pisze się dla aktora, bo to on codziennie nosi tekst w przedstawieniu, on jest tą żywą materia, która komunikuje się z widzem. Jeżeli aktor ma dobra, sensownie napisaną rolę, to ona się przeniesie na widownięę ${ }^{13}$.

Antologia tekstów teatralnych Pawła Demirskiego to znaczący ślad indywidualnej, autorskiej praktyki pisania dla teatru - blisko sceny, w splocie relacji międzyludzkich, które stanowią okoliczności napędzające i kształtujace powstawanie tekstu. Książka w swym treściowym, kompozycyjnym i edytorskim kształcie wpisuje się ponadto $\mathrm{w}$ rejestr praktyk artystycznych szerszego rzędu, a mianowicie stanowi znakomite świadectwo zmian zachodzących podczas produkcji przedstawien - w dynamicznym splocie działań artystycznych i towarzyszących, skupionych wokół teatru jako instytucji, ale dalekich od modelu inscenizowania tekstu uprzedniego względem przedstawienia. Nie bez powodu wstęp do antologii nosi tytuł: Od przedstawienia do tekstu - i z powrotem. Brzmienie tych słów nawiązuje do równie wyrazistego tytułu pracy Patrice'a Pavisa, teoretyka inscenizacji teatralnej. W 1989 roku w „Dialogu” został opublikowany artykuł Od tekstu do przedstawienia: trudny poród ${ }^{14}$. Porównując oba tytuły, nietrudno spostrzec zasadniczą zmianę kierunku wektora relacji tekstu i spektaklu teatralnego. Patrice Pavis pisał o inscenizacji jako „urzeczywistnionym”, „kolektywnym” odczytaniu tekstu. Wyodrębnił też metatekst inscenizacji: „to znaczy jakby jej własny komentarz do tekstu dramatycznego, odczytanie sceniczne, które ów komentarz proponuje" ${ }^{15}$. W tym sposobie myślenia, stanowiącym pokłosie Ingardenowskiej teorii konkretyzacji, znaczenie wypowiedzi scenicznej jest efektem interpretacji tekstu uprzedniego względem spektaklu. Twórczość teatralna Pawła Demirskiego „dzieje się” natomiast na innych zasadach. Na początku pracy nad spektaklem pojawia się zarys tekstu, prezentowany

${ }^{12}$ Zob. W.B. Worthen, Dramat: między literaturq a przedstawieniem, przeł. M. Borowski, M. Sugiera, Kraków 2013, s. 40-44, 78.

${ }^{13}$ NIE dzieci w krótkich gaciach. Rozmowa z Pawtem Demirskim, portal teatralny.pl, 2014, https://teatralny.pl/rozmowy/nie-dzieci-w-krotkich-gaciach,501.html (dostęp: 24.05.2021).

${ }^{14}$ P. Pavis, Od tekstu do przedstawienia: trudny poród, przeł. M. Sugiera, „Dialog” 1989, nr 8.

${ }^{15}$ Ibidem, s. 109. 
aktorom jako materiał przyszłej sytuacji teatralnej, impuls do poszukiwań „miejsc wspólnych” w zespołowym projektowaniu świata scenicznego. Autor testuje w ten sposób swoje pisarskie założenia. „Jego dramaturgia powstaje w styczności z procesem prób, mimo że on sam od pewnego momentu rzadko na nich bywa" - stwierdza Juliusz Chrzasstowski podczas rozmowy z aktorami Teatru Starego, opublikowanej w antologii ${ }^{16}$. Demirski pisze równolegle do pracy zespołu teatralnego pod okiem reżyserki; inspiruje go kontakt z aktorami, ale nie „pisze na scenie”, bo poszerzona, „ostateczna” wersja tekstu to efekt pracy twórczej w odosobnieniu. Nie jest to zatem typowa praca dramaturga, który jako

asystent, kreatywny krytyk i krytyczny współpracownik [...] zajmuje się gromadzeniem materiału, jego selekcja, przygotowaniem komentarzy, w czasie prób pomaga reżyserowi i zespołowi orientować się w rozległych często źródłach, na podstawie których toczy się praca ${ }^{17}$.

Dramaturgia Demirskiego to praktyka naznaczona autorytetem autora jako twórcy dzieła pisanego. I w tym sensie różni się ona od dobrze znanych teatralnych praktyk wspólnotowych, od zespołowego pisania na scenie, zapoczątkowanego w erze kontrkultury i charakterystycznego dla teatrów awangardowych. Było to zjawisko symptomatyczne dla teatru drugiej połowy $\mathrm{XX}$ wieku i zostało już precyzyjnie opisane ${ }^{18}$, a wspominam o tym pokrótce po to, by uwypuklić specyfikę twórczości teatralnej Pawła Demirskiego. Uważna lektura nowo wydanej antologii odsłania tajniki jego warsztatu pisarskiego i daje wgląd $\mathrm{w}$ dramaturgię ( $\mathrm{w}$ sensie napięcia $\mathrm{w}$ przebiegu zdarzeń) wieloetapowego procesu współtworzenia warstwy słownej widowiska teatralnego, przebiegającego w sposób nielinearny, poza porządkiem przyczynowo-skutkowym, na zasadzie sprzężenia zwrotnego między osobą pisząca dla sceny a zespołem twórców przedstawienia (reżyserką i aktorami). Jest to niewątpliwie twórczość powstająca z myślą o wykonawcach tekstu scenicznego. W rozmowie z aktorkami i aktorami Starego Teatru zamieszczonej na początku antologii, stanowiącej ważne wprowadzenie do lektury tekstów Demirskiego, czytamy:

JULIUSZ CHRZA_STOWSKI: Zawsze czuję satysfakcję, że Paweł, rozwijając postać, na jakimś etapie pisze ją pod aktora, że monologi, które się z czasem pojawiaja, wynikają z obserwacji energii aktorskich, z którymi Paweł ma do czynienia. Praca

${ }^{16}$ Wejście na obszar, w którym wszystko jest możliwe. Rozmowa $z$ aktorami i aktorkami Starego Teatru, [w:] P. Demirski, op. cit., s. 21.

${ }^{17}$ W. Baluch, op. cit., s. 58.

${ }^{18}$ Zob. artykuły w monograficznym numerze Zawód: dramaturg, „Notatnik Teatralny” 2010, nr 58-59. 
z wieloma niewiadomymi jest super wyzwaniem. Natomiast faktycznie, jeżeli chce się ogarnąć całość, chce się pojąć, w czym się bierze udział, w czym gramy, o czym opowiadamy, to nawet na etapie pierwszej próby generalnej jest to praktycznie niemożliwe. Wtedy dopiero powstaje montaż scen. Poszczególne sceny często nam aktorom się nie łączą, ale Monika je łączy. Dopiero po premierze jestem w stanie zrozumieć całą historię. Gdybym był w innym teatrze, pewnie pomyślałbym, że to jest dość ryzykowny eksperyment. Przecież to jest wbrew regułom tworzenia teatru dramatycznego. Słowo jest podstawą wszystkiego. Jak tu wyruszyć w jakaśs drogę, skoro nie mamy podstawowego narzędzia, kompasu?

To się może wydawać szokujace. Znam innych twórców, którzy też chca pisać w trakcie prób i zasysać materiał z aktorów, ale to niekoniecznie przynosi dobre efekty. To specyfika pisania Pawła i chyba tylko jemu udaje się to dobrze zrealizować.

$[\ldots]$

DOROTA POMYKAŁA: Wiadomo, że teksty rodzą się w głowie Pawła w różnym czasie. Ale nie naciskamy na niego, bo wiemy, że zdąży. Czekamy cierpliwie, bo przynosi nam coś takiego, od czego aż zapiera dech w piersiach. Mam wrażenie, że na próbach Paweł zagląda do naszych dusz i potem przynosi je nam podane na papierze. Oczywiście, że to są role. Ale role pogłębione o nas samych. Uwielbiam ten dreszczyk emocji, kiedy dostajemy kolejne partie tekstów. Każdy szybko kartkuje, ciekawy swojej roli, słów, jakie wypowiada. Co się za nimi kryje, jaki świat? Czasami czegoś nie wiemy, bo składnia fenomenalnych tekstów Pawła nie należy do najłatwiejszych. Ale wtedy wkracza Monika i wie. Po prostu wie, jak je odczytywać ${ }^{19}$.

\section{IV}

Antologia pt. Teksty dla (Starego) Teatru zawiera pięć sztuk scenicznych Pawła Demirskiego. Sa to: Bitwa warszawska 1920; nie-boska komedia. WSZYSTKO POWIEM BOGU!; Trumf woli; Rok z życia codziennego w Europie Środkowo-Wschodniej oraz Jeńczyna. Sztuka dla dorostych. Wszystkie te utwory sa werbalnymi świadectwami przedstawień powstałych na zamówienie Narodowego Starego Teatru w Krakowie w latach 2013-2020. Opublikowany zbiór tekstów pęcznieje od znaczeń w co najmniej potrójnym aspekcie - i to pomijając podstawową kwestię, czyli możliwość interpretacji każdego z tych utworów, stanowiących „kompletne” projekty literackie same w sobie, osobno.

Po pierwsze zatem, antologia dokumentuje etap pracy Moniki Strzępki i Pawła Demirskiego w Narodowym Starym Teatrze, co świadczy o ugruntowanej pozycji tego duetu wśród ważnych i liczących się współczesnych

${ }^{19}$ Wejście na obszar, w którym wszystko jest możliwe..., ed. cit., s. 21. 
twórców polskiego teatru. To zjawisko o tyle ciekawe, że artyści jako zadeklarowani przedstawiciele teatru krytycznego, antysystemowego, ostrego w środkach („Ich teatr powstał ze świadomego rabunku - okradania elit, mediów i społeczeństwa z najbardziej wyświechtanych przekonań na temat naszej przeszłości, bieżącej polityki i sztuki” - pisał Łukasz Drewniak ${ }^{20}$ ), nie tracąc nic ze swej bezkompromisowości i radykalności, odbyli w czasie pracy artystycznej zdecydowany marsz z prowincji ku centrum (i dalej realizuja z powodzeniem oraz głośnym oddźwiękiem krytycznym kolejne spektakle nie tylko w krakowskim Teatrze Narodowym, lecz także na innych znaczacych scenach, np. w Warszawie czy Poznaniu).

Po drugie, zgromadzone w antologii teksty układają się w zbiór najbardziej charakterystycznych cech poetyki Pawła Demirskiego. Jego pisanie dla teatru, określane jako „podważanie siebie”, „programowa niekonsekwencja” czy „gra z odbiorczymi przyzwyczajeniami, oczekiwaniami i opiniami”"21, ma głęboko sensualny wymiar, jest reakcją na bodźce świata zewnętrznego, które drażnia, prowokują i uruchamiają sarkastyczny ogląd rzeczywistości. Rzecz dotyczy zarówno konkretnych wydarzeń społeczno-kulturalnych (w tych kategoriach można postrzegać Bitwę warszawska 1920 - jako reakcję na dzieło filmowe w reżyserii Jerzego Hoffmanna), jak i zjawisk bardziej ogólnych, ale niepokojących ze względu na ich skuteczność w procesie zarażania ludzkich umysłów - w tym celu Demirski przywołuje i rozmontowuje różne dyskursy i obiegowe narracje ${ }^{22}$, stanowiące poręczne narzędzie sterowania zbiorowością i instrumenty sprawowania władzy (przykładem niech będzie utwór nie-boska komedia. WSZYSTKO POWIEM BOGU!). W „ruchu od”, w gestach reakcji i sprzeciwu, będących de facto przykładami „polityczności” teatru „na papierze” Pawła Demirskiego, sporo miejsca zajmuja techniki przepisywania literackiego kanonu czy też parafrazowanie różnych tekstów kultury, co skrupulatnie analizowała Joanna Krakowska ${ }^{23}$. Nie ma zatem pełnej satysfakcji i uciechy w odbiorze tekstów Demirskiego, jeśli nie odkrywa się w nich pokładów aluzji i stylizacji, także w odniesieniu do sfery zjawisk plebejskich czy popularnych (casus Triumfu woli, uznanego za jeden z bardziej pozytywnych przekazów teatralnych autorstwa Pawła Demirskiego i Moniki Strzępki).

${ }^{20}$ 七. Drewniak, Bonnie i Clyde, czyli teatralny blitzkrieg Strzępki i Demirskiego, „Przekrój” 2010, nr 51, http://encyklopediateatru.pl/artykuly/108272/bonnie-i-clyde-czyli-teatralny-blitzkrieg-strzepki-i-demirskiego (dostęp: 24.05.2021).

${ }^{21}$ A. Dąbek, op. cit., s. 8.

${ }^{22}$ Pisał o tym na przykład P. Dobrowolski w książce Teatr i polityka. Dyskursy polityczne w polskiej dramaturgii wspótczesnej, Poznań 2019.

${ }^{23}$ Zob. J. Krakowska, Demi(d)ramy, [w:] P. Demirski, Parafrazy, Warszawa 2011. 
Tak się akurat złożyło, że pięć utworów scenicznych zamieszczonych $\mathrm{w}$ antologii stanowi reprezentatywną część dorobku dramaturgicznego autora - w wymiarze stylistycznym, kompozycyjnym i światopoglądowym. Układ tekstów, a także otaczające je materiały dodatkowe (przede wszystkim rozmowy z twórcami) pozwalają dostrzec również pewną zmianę w autorskim sposobie myślenia o bohaterach. Dotychczasowy Demirski przyzwyczaił widzów teatralnych do postaci „wewnętrznie sprzecznych”, złożonych z wielu różnych skłonności, zachowań, ról. Tworzył na bazie stereotypów, nie stronił od karykatury, dosadnego języka i brzydoty. Budował swych bohaterów nieliniowo, z pęknięć i kontrastów, grą skojarzeń i programową rezygnacją z ciagu przyczynowo-skutkowego w kompozycji scen. W warstwie stylistycznej zaś - albo ze szczątkowych wypowiedzi, albo z wykorzystaniem nadmiernie rozbudowanych replik o pogmatwanej składni, niesłychanie rytmicznych i zarazem dość trudnych w lekturze. W tej materii słownej nie zawsze jasno była dookreślana sytuacja wypowiadania, nie zawsze był sygnalizowany kontekst, który ułatwiałby rozpoznanie miejsca bohatera w świecie przedstawionym. Demirski jako komentator swoich tekstów zgromadzonych w antologii, a także jako autor Jeńczyny (premiera: 31.12.2020) odsłania natomiast inne oblicze relacji z postaciami: mówi o traktowaniu ich „z czułością” (sic!), co pozwala w zbliżeniu bądź w kameralnym ujęciu, w niedomówieniach, z pewnego rodzaju empatią kreować prywatne, zakulisowe, afektywne reakcje czy to bohaterów „wielkiej historii” (np. Piłsudski z Bitwy warszawskiej 1920), czy uczestników życia codziennego w ich niecodziennych skłonnościach i zachowaniach tabuizowanych (np. różne problemy seksualne bohaterów Jeńczyny).

Po trzecie wreszcie, opublikowane teksty teatralne stanowia postzapis, odpowiednio zredagowane wersje scenariuszy spektakli. Sa to utwory przygotowane do druku po premierze przedstawien, a ich edytorski kształt został wypracowany przed redaktorkę antologii w porozumieniu z autorem i z myśla o czytelniku, o ułatwieniu lektury niełatwych przecież kompozycji słownych. Fakt tej „pracy na tekstach”, ujawniony we wstępie do tomu, zwiększa poziom refleksyjności podczas lektury książki - uważny czytelnik może mieć wrażenie, że obcuje z zastygniętym w bezruchu graficznym słowem mówionym, ma pośredni dostęp do żywiołu mowy scenicznej, a wraz z nim - do zdarzeniowego wymiaru spektaklu. To wrażenie może być silniejsze w razie znajomości spektakli, a pogłębia je otoczka materiałów dodatkowych, czyli opublikowane w tomie rozmowy z aktorami, poświęcone etapom i szczegółom pracy nad spektaklami. Metaforycznie rzecz ujmując, akt czytania przebiega w następującym kierunku: „od lektury tekstu do przedstawienia”, odbywa się w procesie przypominania sobie zdarzeń scenicznych - zarówno w ich wymiarze fikcyjnym, jak i realnym. Rozwija się w splocie słów i obrazów, wskutek 
konfrontacji znaczeń zawartych w zapisie i pamięci o „rzeczach czynionych” na scenie. Doświadczenie estetyczne kształtuje się zatem w „splątaniu” ${ }^{44}$ jest wynikiem czytania tekstu / widzenia spektaklu.

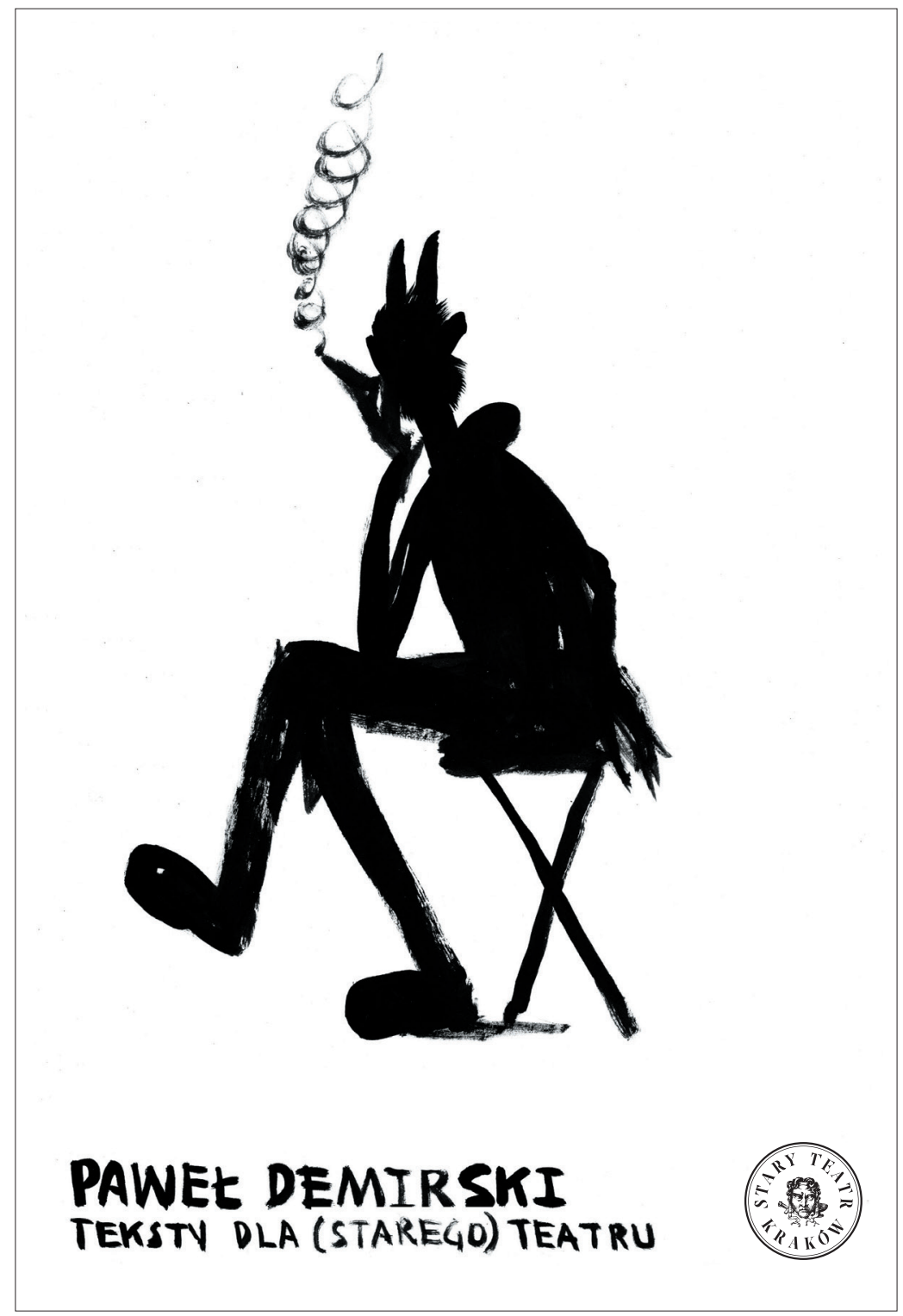

Autorem grafiki okładki jest Bolesław Chromry.

${ }^{24}$ Używam tego pojęcia w nawiązaniu do rozważań A. Krajewskiej. Zob. A. Krajewska, Humanistyka performatywna, „Przestrzenie Teorii” 2018, nr 9. 


\section{Pointa}

Interesujący mnie w tych rozważaniach splot okoliczności, czyli publikacja antologii tekstów teatralnych Pawła Demirskiego jako ślad pracy artystycznej w Narodowym Starym Teatrze, świadectwo poetyki autora oraz praktyka utrwalania wypowiedzi scenicznej w formie zapisu zredagowanego po przedstawieniu, pozwala sformułować wniosek o dramaturgii odbioru tego projektu wydawniczego. Jest to efekt recepcji w pewien sposób zaprogramowany przez współtwórców publikacji, skomponowanej z różnych porcji materiału tekstowego, na zasadzie konfrontacji różnych podmiotowych punktów widzenia zespołu artystów i ludzi teatru (dramaturga, kierowniczki dramaturgów, aktorów, inspicjentki). Tak skomponowana książka staje się żywym archiwum teatru, a podjęcie jej lektury - performatywnym gestem uruchomienia różnych danych, w zależności od przygotowania i oczekiwań czytelnika. Warto podkreślić istotność

tej artykulacyjnej pracy, którą bierze na siebie czytelnik (a każdy trochę to robi inaczej), aktualizując znaczenie tekstu za sprawa reaktywowania w lekturze zasobów własnej wiedzy, przeżyć i wrażliwości, osadzających się w sieci kulturowych wzorców wspólnotowego doświadczenia ${ }^{25}$.

Lektura Tekstów dla (Starego) Teatru to z pewnością osobliwe przeżycie estetyczne, które ma swój wymiar egzystencjalny - jest pełnym dramaturgii doświadczeniem reorientacji w sposobie myślenia o związku między tekstem a scena, bez jednoznacznych rozstrzygnięć, co jest pierwsze, ważniejsze, skuteczniejsze; bez myślenia hierarchicznego i binarnych podziałów. Wynikająca z lektury książki przyjemność estetycznego obcowania z wieloma aspektami twórczości teatralnej może prowadzić odbiorcę do pogłębionego doświadczenia dramaturgii bycia - w procesie przydarzania się rzeczy, przypominania sobie tego, co „było czynione”, a także - dzięki świadomości afektywnego współuczestnictwa - w różnych działaniach artystycznych i pozaartystycznych.

\section{BIBLIOGRAFIA}

Baluch W., Dramaturgia, [w:] Performatyka. Terytoria, red. E. Bal, D. Kosiński, Kraków 2016.

Dąbek A., Od przedstawienia do tekstu - i z powrotem, [w:] P. Demirski, Teksty dla (Starego) Teatru, red. A. Dąbek, Kraków 2020.

${ }^{25}$ R. Nycz, op. cit., s. 146. 
Demirski P., Teksty dla (Starego) Teatru, red. A. Dąbek, Kraków 2020.

Dobrowolski P., Teatr i polityka. Dyskursy polityczne w polskiej dramaturgii wspótczesnej, Poznań 2019.

Dramaturg w teatrze, literaturze, sztuce, red. W. Baluch, A. Krajewska, Poznań 2019.

Drewniak Ł., Bonnie i Clyde, czyli teatralny blitzkrieg Strzępi i Demirskiego, „Przekrój” 2010, nr 51, http://encyklopediateatru.pl/artykuly/108272/bonnie-i-clyde-czyli-teatralny-blitzkrieg-strzepki-i-demirskiego (dostęp: 24.05.2021).

Kosiński D., Performatyka. W(y)prowadzenia, Kraków 2016.

Krajewska A., Dramatyczna teoria literatury. Zarys problematyki, Poznań 2009.

Krajewska A., Humanistyka performatywna, „Przestrzenie Teorii” 2018, nr 9.

Krakowska J., Demi(d)ramy, [w:] P. Demirski, Parafrazy, Warszawa 2011.

NIE dzieci w krótkich gaciach. Rozmowa z Pawtem Demirskim, portal teatralny.pl, 2014, https://teatralny.pl/rozmowy/nie-dzieci-w-krotkich-gaciach,501.html (dostęp: 24.05.2021).

Nycz R., Poetyka doświadczenia, Warszawa 2012.

Pavis P., Od tekstu do przedstawienia: trudny poród, przeł. M. Sugiera, „Dialog” 1989, nr 8.

Worthen W.B., Dramat: między literatura a przedstawieniem, przeł. M. Borowski, M. Sugiera, Kraków 2013.

Zawód: dramaturg, „Notatnik Teatralny” 2010, nr 58-59.

Beata Popczyk-Szczęsna - dr. hab., prof. w Instytucie Nauk o Kulturze na Wydziale Humanistycznym Uniwersytetu Ślaskiego. Autorka książek: Postać Judasza w dramacie polskim XX wieku. Potyczki z referencja (Kraków 2003), Dramaturgia polska po 1989 roku (Katowice 2013), Powtórzenia i powroty. O dramaturgii Janusza Gtowackiego (Katowice 2015), Tekst jako bohater w kulturze uczestnictwa. Szkice o polskiej dramaturgii teatralnej (Katowice 2019). Współredaktorka tomów zbiorowych: Dramat i doświadczenie (2014), Pisanie dla sceny - narracje wspótczesnego teatru (2019). Zajmuje się dramatem i teatrem XX wieku w kontekście artystycznych i społecznych praktyk performatywnych, teoria i praktykami lektury tekstu dramatycznego, najnowszą polską dramaturgią sceniczna, biografia w teatrze XXI wieku oraz doświadczeniem jako kategorią teoriopoznawcza we współczesnej refleksji humanistycznej. ORCID: 0000-0001-8924-8093. Adres e-mail: <beata.popczyk-szczesna@us.edu.pl>.

Beata Popczyk-Szczęsna - PhD, (dr hab.), professor at the Institute of Culture Studies, University of Silesia in Katowice (Poland). Author of the following books: The figure of Judah in the Polish drama of the $20^{\text {th }}$ century. Clashes with the reference (Kraków 2003), Polish dramaturgy after 1989 (Katowice 2013), Repetitions and returns. About dramatic works of Janusz Gtowacki (Katowice 2015), Text as a hero in the culture of participation. Sketches of Polish theatrical dramaturgy (Katowice 2019). Co-editor of the collective work: Drama and experience (Katowice 2014), Writing for the Stage Narratives in Contemporary Theatre (Katowice 2019). She deals with theory and the practices of reading drama texts, recent Polish stage dramaturgy and biography in $21^{\text {th }}$-century theatre. ORCID: 0000-0001-8924-8093. E-mail address: <beata.popczyk-szczesna@us.edu.pl>. 
